\title{
St Wærburh: The Multiple Identities of a Regional Saint
}

\author{
Alan Thacker
}

The saint's cult discussed in this chapter originated in Mercia but was promoted over a wide area, including Chester and, eventually, a monastery which as been described as "to all intents and purposes a West Saxon institution."1 As such it forms a particularly fitting subject for a volume in honour of Barbara Yorke who has written so extensively and influentially about Anglo-Saxon Wessex in particular and the royal women of Anglo-Saxon England as a whole. This chapter has had an extremely long gestation-I first wrote about St Wærburh in the early 1980 - - and it is with great pleasure that I finally present it here to a scholar whose work has made us all rethink our views about Anglo-Saxon kingship and the religious communities and cults that it engendered.

The traditions relating to St Wærburh and her relics are well-known. She was the daughter of King Wulfhere of Mercia (657-75) and his wife Eormenhild, and through her mother was closely connected with both the Kentish and East Anglian royal families. She early showed a disposition towards the religious life, and entered the monastery of Ely where her great aunt Æthelthryth was abbess. She remained for some time at Ely, where according to some sources she succeeded her grandmother Seaxburh and her mother Eormenhild as abbess, but was recalled to Mercia by her uncle, King Æthelred, Wulfhere's brother and successor $\left(675^{-704}\right)$, and given authority over the nunneries of his kingdom. She performed miracles while living on her father's estate at Weedon (Northants) and died about 700 in her monastery of Triccingham (almost certainly Threekingham, Lincs.). After some dissension, she was buried in accordance with her wishes in the monastery of Hanbury, near Repton (Staffs.), where nine years later, in recognition of her sanctity, her remains were elevated at the command of her cousin, the Mercian king Ceolred (709-16), and were found to be miraculously preserved and uncorrupted. Her relics remained enshrined at Hanbury until the time of the Danish invasions, shortly after which

1 S.J. Ridyard, The Royal Saints of Anglo-Saxon England (Cambridge, 1988), p. 189. 
they were removed to Chester where they lay until the destruction of her shrine in the 1530 s. $^{2}$

What follows will re-examine this material in relation to the five centuries or so from about 700 to 1200 . My reasons for doing so are not only that it has intrinsic interest, but-more importantly-because the reinventions and relocation of St Wærburh in the earlier middle ages illustrate with especial clarity the ways in which a saint's cult could be promoted and adapted as the focus of changing dynastic, local, regional and civic identities. I shall begin by looking at the written sources and at the community which produced the principal Vita associated with the cult (surprisingly enough one which never housed Wærburh's relics). Then I shall go back to the cult's origins and diffusion in two early English kingdoms, and lastly focus upon its relocation to a new urban environment in Chester.

\section{The Sources}

Since I first worked on this material in the 1980 s, the most crucial source, the short anonymous Latin Life, has been edited by Rosamond Love. ${ }^{3}$ As in many respects, we came to similar conclusions, here I shall simply summarise my main arguments about the texts before moving on to look at the evolution of the cult itself. The sources for Wærburh's story are scanty and diverse. Besides the fundamental Vita S. Werburgae, there are important, if brief notices of the saint in a number of 12th-century century sources, including of John of Worcester's Chronicle, Henry of Huntingdon's Historia and William of Malmesbury's Gesta pontificum. ${ }^{4}$ Other traditions about Wærburh and her relics are related in the 12th-century history of the abbey of Ely (the Liber Eliensis), ${ }^{5}$ in the Latin Lives and lections of Eormenhild and Seaxburh, ${ }^{6}$ and in the passio of the saint's supposed brothers, Wulfhad and Ruffinus, an almost entirely fictional,

2 For summaries of her life and cult see Alan Thacker, "Werburh [St Werburh, Werburgh, Werburga] (d. 700×07), Abbess," ODNB, <https://doi.org/10.1093/ref:odnb/29062>; J. Tait, ed., Chartulary of Chester Abbey, 2 vols, Chetham Society, new series 79, 82 (Manchester, 1920-3), 1:viii-xiv; Rosalind Love, ed. and trans., Goscelin of Saint-Bertin. The Hagiography of the Female Saints of Ely (Oxford, 2004), pp. xv-xvii.

3 Vita S. Werburgae (VWer), in Socii Bollandanii, Bibliotheca Hagiographica Latina, ed. Henryk Fros $[B H L]$, 4 vols (Brussels, 1898-1985), no. 8855; Love, Goscelin, pp. 25-51 (references to $V W e r$ hereafter are to Love's edition).

4 JW vol. 2, p. 126; HH, pp. 692-94; WM, GPA, 1:172.5-9, 183.3 (pp. 466-68, 488).

$5 \quad L E$ I.15, 17, 24, 36, ed. Blake, pp. 32, 35, 42, 52.

6 BHL, nos. 7694, 2611; both edited by Love, Goscelin, pp. 1-23, 133-89. 
probably post-Conquest, fabrication. ${ }^{7}$ There are also two later sources, both by monks of Chester abbey: the 14th-century Polychronicon of Ranulf Higden ${ }^{8}$ and the early 16th-century English verse Life of the saint by Henry Bradshaw. ${ }^{9}$ In addition, the cult is mentioned in various late Anglo-Saxon lists of the resting-places of English saints ${ }^{10}$ and in a number of 11th- and 12th-century calendars, ${ }^{11}$ and is represented in scattered ancient parish church dedications. ${ }^{12}$ In its present form, all this material is late, very little if any of it from before the 11th century, i.e. at least 300 years after Wærburh's death.

In considering this evidence, perhaps the most important problem is the date, reliability, and provenance of the anonymous Vita Werburgae. In its final form this work was probably written around 110o: its conclusion refers to bodies of early English saints that had survived incorrupt for over 400 years, while its prologue mentions Wærburh's relatives, Cyneburh, Cyneswith and Tibba, as resting at Peterborough, to which monastery they had only been transferred in $963 .{ }^{13} \mathrm{~A}$ further indicator is a lengthy miracle story, that of the wild geese, who damage the saint's crops on her royal estate at Weedon and are brought to repentance, one of their number having been stolen and restored to them by Wærburh; as the author himself acknowledged that anecdote closely resembles an incident in the Life of the Belgian saint Amalburg, which he himself had fashioned, and which was probably written in Flanders in the later nth century. ${ }^{14}$

Despite these pointers, careful examination of the text suggests that at its core lay accounts of the saint's miracles, and more particularly of her death, burial and elevation, likely to have originated in Hanbury, the saint's first restingplace, perhaps in the 8th or 9th century. The Vita recounts that Wærburh had

BHL, nos. 8735-6; Acta Sanctorum, Jul. v (1727), pp. 571-82; P. Grosjean, "De Codice Hagiographico Gothano"; "Codicis Gothani Appendix," Analecta Bollandiana 58 (1940), 90-103, 177-204, at pp. 93, 183-87.

C. Babington and J.R. Lumby, eds., Polychronicon Ranulphi Higden monachi Cestrensis, RS 41, 9 vols (London, 1865-86), 6:126, 176-77, 366.

9 C. Horstmann, ed., Life of Saint Werburge of Chester, by Henry Bradshaw, EETs OS 88 (London, 1887).

10 D.W. Rollason, "Lists of Saints' Resting-Places in Anglo-Saxon England," ASE 7 (1978), 61-93, at p. 73, n. 3; p. 84; idem, The Mildrith Legend. A Study in Early Medieval Hagiography in England (Leicester, 1982), pp. 28-29, 44, 84-85, 87; Felix Liebermann, Die Heiligen Englands (Hanover, 1889), pp. 7-8.

11 Francis Wormald, ed., English Kalendars before AD 1100, HBS 72 (1934 for 1933); Rebecca Rushforth, Saints in English Kalendars before 1100, HBS 117 (2008 for 2005); F. Wormald, ed., English Benedictine Kalendars after AD 1100, 2 vols., HBS 77, 81 (1938-46).

12 F. Arnold-Forster, Studies in Church Dedications, 3 vols (London, 1899), 2:378; 3:451.

$13 V W e r$, Chs. 1, 11 (pp. 32, 48); Rollason, Mildrith Legend, pp. $26-27$.

14 VWer, Ch. 6 (pp. 40-42); Love, Goscelin, p. lxxvii. 
chosen Hanbury as her resting-place, wheresoever on her estates she might die. In fact she died at Threekingham, where the community locked the body away intending to retain it for themselves. Nevertheless, it was miraculously delivered to the people of Hanbury (Heanburgenses), come to collect it, when by divine will the watchmen were overcome by sleep and the locks and bars they had installed fell to the ground. ${ }^{15}$ Thereafter the saint was taken to Hanbury, where she performed many miracles and where after nine years later her imperishable body was elevated at King Ceolred's command. ${ }^{16}$

The reworking and augmenting of this core text was once thought to have been commissioned by the monks of Chester. ${ }^{17}$ That, however, is extremely unlikely. Although the prologue alludes perfunctorily to Wærburh's restingplace in the city, the rest of the Vita contains no reference to the translation to Chester, to the saint's shrine there or to the minster and the Benedictine monastery that succeeded it. Moreover, it refers uncompromisingly to the disintegration of the saint's hitherto incorrupt body, which at the moment of removal from Hanbury yielded to the laws of mortality, lest it fall into the invaders' impious hands, an event that the new custodians would surely not have wished to advertise. ${ }^{18}$ If Chester be excluded, the community with the greatest reason to remember Wærburh around 1100 was Ely, the burial place of her mother Eormenhild, her grandmother Seaxburh, and her great aunts Æthelthryth and Wihtburh. ${ }^{19}$ The manuscript certainly points to an Ely provenance. ${ }^{20}$ Moreover the author of the Life of Wærburh expressly commends the tomb of Eormenhild at Ely as the place at which Wærburh's aid should be invoked. ${ }^{21}$ It is unlikely in the extreme that a Life composed for the monks of Chester would have recommended this as an appropriate place to obtain Wærburh's

15 On Hanbury and it association with St Wærburh, see $V c H$ Staffs. 10, pp. 125-48, esp. 137-38.

16 VWer, Chs. 8-11 (pp. 44-48).

17 See e.g. $V Æ d R$, and ed., p. 111.

18 VWer, Ch. 12 (pp. 48-50).

19 See below.

20 For discussion of these manuscripts see now, Love, Goscelin, pp. xlviii-lviii. Of the six surviving medieval copies of the Vita, three occur in 12th-century manuscripts closely associated with Ely and devoted to Ely hagiography: Trinity College Cambridge, MS 0.2.1; Corpus Christi College Cambridge, MS 393; BL, Cotton MS Caligula A viII, fols. 59-191. Another is from neighbouring Ramsey: Bodleian Library, MS Bodl. 285. Even the now lost Chester copy of the Vita, which provided material for the first book of Bradshaw's poem, seems to have made use of Lives of the Ely abbesses, Æthelthryth, Seaxburh and Eormenhild, and perhaps derived from an Ely manuscript: Bradshaw, Life, esp. I, lines 1982-2275 (pp. 75-84).

21 Lectiones in natale Sancte Eormenhilde [Lect.Eorm], ed. Love, Goscelin, pp. 11-23, at Ch. 5 (p. 16). 
intercession. We may therefore take it as reasonably certain that the Life in its extant form was written at that monastery, around the time of the translations there of Wærburh's close relatives in 1106 (a subject to which I shall return shortly). Although the longstanding assumption that the anonymous author was Goscelin has been questioned, the Life's most recent editor has persuasively reaffirmed the traditional attribution. ${ }^{22}$

\section{The Cult of Wærburh and Her Relatives at Ely}

The history of the cult of Wærburh's relatives at Ely is a complex matter, in a large part obscure. The life of the community was disrupted by Danish attacks in the late gth century and any traditions about its early years that had survived up to then were irrevocably lost. ${ }^{23}$ The cult of the foundress Æthelthryth undoubtedly continued, however, and the restoration of the community by St Æthelwold in 970 inaugurated a revival of interest in the cult of that saint and her relatives, Wærburh's forbears. In 974, the remains of Æthelthryth's sister Wihtburh, who had lived as a recluse at Dereham (Norfolk), were brought to Ely. At much the same time the bodies of Eormenhild and Seaxburh were translated to new shrines by St Æthelwold. ${ }^{24}$ It was at that time perhaps that the community began to develop that interest in sanctified incorruption which is so marked a feature of its hagiographical writings, including the Vita Werburgae; for Wihtburh's body, like her sister Æthelthryth's, was reputed imperishable. ${ }^{25}$ There is no evidence, however, that Wærburh herself was culted at Ely in this period; her feast day does not, for example, occur in the early 11thcentury calendar in the missal of Robert of Jumièges, which has strong connexions with Ely. ${ }^{26}$ Nor does she appear in the earliest post-Conquest Ely litany. ${ }^{27}$

In the early 12th century there was a renewed interest in the cult of the Ely princesses, promoted by the new abbot, Richard of Clare after his return from a

22 Love, Goscelin, esp. pp. lxxi-lxxviii. Cf. Ridyard, Royal Saints, p. 6o; Rollason, Mildrith Legend, pp. 26-27, where the text is treated as anonymous.

23 Ridyard, Royal Saints, p. 181-85; VCH Cambs. 2, p. 99.

24 Vita S. Wihtburge (hereafter VWiht), Chs. 9-14, in Love, Goscelin, pp. 66-75 and BHL, no. 8979 (citations from Love's edition); LE II.53, 145-46 (pp. 120-23, 230-31).

25 VWiht, Chs. 7-8 (pp. 64-67).

26 J.B.L. Tolhurst, "An Examination of Two Anglo-Saxon mss of the Winchester School," Archaeologia 83 (1933), pp. 27-44. Cf. Ridyard, Royal Saints, pp. 179-80 n. 20, 209-10 n. 151.

27 N. Morgan, ed., English Monastic Litanies of the Saints, HBS 119 (2012), no. 30 (pp. 24, 104-07). 
visit to Rome in the company of Archbishop Anselm. In 1106 the saints' bodies were removed from the resting-places allotted to them by Æthelwold and translated to new monuments in Abbot Richard's new monastic choir. The discovery of Wihtburh's still uncorrupted body gave fresh impetus to the devotion. ${ }^{28} \mathrm{Af}-$ ter, or in association with, these events we find a flourishing literary tradition, with which the Vita Werburgae is closely connected, and which includes Lives and Miracles of Æthelthryth, Seaxburh, and Wihtburh. ${ }^{29}$ Thereafter we also find all the Ely princesses given prominence in the Ely calendar, which commemorates both the depositions and translations of those actually enshrined there. Wærburh herself is also included but with less emphasis. She is only commemorated on 3 February, the day of her death and deposition; her Chester translation feast is ignored. ${ }^{30}$ Nevertheless, her association with the celebration of the Ely saints, two of whose bodies were reputed to be imperishable, suggests her Vita's emphasis on the initial incorruption and subsequent disintegration of her body is related to the East Anglian community's preoccupations in 1106.

The Ely material has been edited and analysed by Love and there is no space to discuss it in detail here. ${ }^{31}$ An outline, however, is essential to understanding the development of the cult as a whole. There are several layers to the tradition about the royal saints of Ely. Its most developed form is related in the history of the Ely community known as the Liber Eliensis, written in the middle decades of the 12th century. The crucial element in this final stage of the Ely version of the legend is the intrusion of a Kentish theme. Seaxburh, Eormenhild, and Wærburh herself were all alleged to be abbesses of the royal Kentish abbey of Minster-in-Sheppey, which Seaxburh had founded. According to the Liber Eliensis, moreover, they all also became successively abbesses of Ely. ${ }^{32}$ This version of events has little to commend it, since Seaxburh died in 695 and Wærburh by 704, leaving little time to fit in the two otherwise unknown Ely abbacies of Eormenhild and of Wærburh herself. Nor does it accord very easily with the well-attested tradition of Wærburh's burial at Hanbury.

Material related to the Kentish traditions recorded in the Liber Eliensis appears in the hagiography of the royal saints of Ely probably compiled more or less contemporaneously. In the Life of Seaxburh, Seaxburh and her daughter Eormenhild are said to have entered religion together in the monastery that

28 VWiht, Chs. 16-24 (pp. 74-83); LE II.143-48 (ed. Blake, pp. 227-34).

29 BHL, nos. 2638, 2639, 7693, 8979, 8980; Love, Goscelin, pp. 53-189, 204-17.

$30 \quad$ Wormald, Eng. Ben. Kal. after 110o, 2:1-19.

31 Love, Goscelin, pp. lviii-cxiii. For earlier discussion, see Ridyard, Royal Saints, esp. pp. 176-210.

$L E$ I.17-18, 24, 35-38 (ed. Blake, pp. 35-36, 42, 51-52). 
the former had founded at Milton. When Seaxburh leaves her later foundation of Minster in Sheppey for Ely she is succeeded there as abbess by Eormenhild, and at her death she is again succeeded by Eormenhild in Ely. ${ }^{33}$ There was, however, clearly an earlier phase in the writing about Ely's saints when the Kentish element of the story was unknown, a phase which produced the original versions of these Lives. In this account, which can probably be attributed to the early 12th century, Eormenhild and Wærburh entered the religious life at Ely, rather than a Kentish minster, and were not believed to have become abbesses of Ely. It is to this phase that the Vita Werburgae belongs. ${ }^{34}$ The reference to Eormenhild's taking the veil at Sheppey in Trinity College Cambridge MS O.2.1 is clearly a later interpolation to bring it into line with the Vita Sexburgae which precedes it in that manuscript. ${ }^{35}$

The source of the Kentish traditions (to which several of these works refer) appears to be what the author of the Life of Seaxburh referred to as "various ancient writings in English" (ex antiquis Anglorum scriptis). ${ }^{36}$ A similar reference to an Old English source occurs also in the Liber Eliensis, in connection with Seaxburh and Eormenhild taking the veil at Sheppey. ${ }^{37}$ Interestingly, a fragmentary Old English text related to this material survives in a manuscript in Lambeth Palace Library. It appears to be a version of the geneaology of the Kentish royal house, the so-called Kentish royal legend, 'customized' as it were for the monastery of Sheppey. Focused primarily on the daughters of King Anna, namely Æthelthryth, Seaxburh and Wihtburh, before breaking off, like the Life of Seaxburh, it relates that Seaxburh and Eormenhild took the veil at the Kentish minster of Milton and that Seaxburh subsequently founded the minster at Sheppey ${ }^{38}$ It also refers to Wærburh resting at Hanbury and shows some knowledge of the Danish invasions. All that suggests that this particular

33 See e.g. Vita S. Sexburgae, ed. Love, Goscelin, pp. 133-88, at chs 8, 15, 19, 24 (pp. 150-52, $166,170,182)$; $B H L$, no. 7693 . Wærburh is mentioned only as Eormenhild's holy offspring (p. 144). See also the revisions made by in MS O.2.1 to VWer and Lect.Eorm (see n. 35).

34 VWer, chs 2-3 (pp. 34-36).

35 The Vita Sexburgae occupies fols. 215-28. The interpolation to VWer, Ch. 3 is at fol. 233. A similar amendment acknowledging the Kentish tradition is made to Lect.Eorm. Ch. 6 (p. 16) at fol. 229v.

$3^{6} \quad$ Vita Sexburgae, prol. (pp. 136-38).

37 "[I]n Anglico quidem legimus": $L E$ I.36 (ed. Blake, p. 51). Cf. the reference to "ancient sources" relating that Wærburh succeeded Eormenhild at Ely in the Book of Miracles included in a late 13th- or early 14th-century Ely manuscript, BL, Cotton MS Domitian A. iv— "ut ex antiquitus scriptis collegisse memini": $L E$, ed. Blake, App. B, p. 400.

38 London, MS Lambeth 427; Rollason, Mildrith Legend, pp. 30-31, 86-87; Love, Goscelin, pp. civ-cvi; O. Cockayne, ed., Leechdoms, Wortcunning and Starcraft, 3 vols, RS (London, 1864-6), 3:430-33. 
text was probably compiled some time between the late gth and earlier 1oth century, and that it represents a tradition that highlighted or enhanced the Kentish elements in the background of Wærburh and her family. That has considerable implications for our understanding of the early development of Wærburh's cult, and it is to those early developments that the discussion will now turn.

\section{The Early Cult of St Wærburh}

Initially, the major centre of Wærburh's cult lay in the heartlands of the Mercian kingdom, at Hanbury, where the saint's remains were elevated and enshrined. Hanbury itself was probably a place of some importance: King Ceolred's presence at Wærburh's elevation suggests that it may well have been the centre of a royal estate, and the name-ending bury links it with a number of other ancient administrative and ecclesiastical centres in the north-west Midlands. The church was probably an early minster. In the Middle Ages it was a valuable rectory and it had a large ancient parish with dependent chapelries. Almost certainly that parish was once even larger and probably included the honorial caput of Tutbury, which cuts through the territory of the later medieval parish. Even in Domesday it remained a manorial centre, with a priest who was still a modest landholder. ${ }^{39}$

Another focus of the cult, also royal according to the stories first recorded perhaps in Hanbury, was Weedon (Northants), the location of Wærburh's most celebrated miracle, that of the wild geese reduced to obedient penitence. ${ }^{40}$ Wærburh's cult was undoubtedly fostered there during the middle ages, for Leland recorded a chapel dedicated to her south of the churchyard. ${ }^{41}$ Adjoining Weedon is a village bearing the significant name of Stowe-Nine-Churches (also Northants). The place-name Stowe, one meaning of which was "holy place," could designate important ecclesiastical centres ${ }^{42}$ and it is significant therefore that Stowe was reputed the burial-place of Ælfnoth ("Alnotus"), according to the Vita Werburgae, a serf of Wærburh's who became a hermit and was martyred by robbers. The Vita records him in terms which suggest that the information was derived from an early resting-place list: "the celebrated man

$39 V$ VCH Staffs. 10, pp. 125-48, esp. pp. 125-26, 128, 137-38.

$40 \quad$ V.Wer., Ch. 6 (pp. 40-42).

41 T. Hearne, ed., The Itinerary of John Leland, 9 vols bound in 3 (Oxford, 1770), 1:11-12.

42 David Roffe, “The Seventh-Century Monastery of Stow Green, Lincolnshire," Lincolnshire History and Archaeology 21 (1986), 31-33, at p. 31; $C D E P N$, p. 583. 
of God lies buried at Stowe, one league from Bugbrook."43 Possibly indeed Stowe was the original mother-church of Wulfhere's estate at Weedon. The numerous churches referred to in the name suggest dependent chapelries; and certainly the pre-Conquest holder, Tonna, was possessed of considerable estates. ${ }^{44}$ Although it is not mentioned in the Domesday Survey, the church bears the plausibly early dedication of SS Peter and Paul, has a late AngloSaxon tower, and contains fragments of late Anglo-Saxon sculpture. ${ }^{45}$

Threekingham, where Wærburh died, presents an interesting parallel. It was clearly an ecclesiastical site of some importance in the pre-Conquest period, since it had two substantial churches at the time of Domesday, both of whose dedications (to St Peter and St Mary) the Survey rather unusually supplies. ${ }^{46}$ It has been plausibly suggested that these were dependencies of a further church, two miles to the south-west, which again has a significant place-name, Stow Green, and that this may have been the site of the monastery in which Wærburh died. The church there, mentioned in Domesday but now disappeared, by the 12th century was dedicated, significantly, to St Æthelthryth of Ely, and in the Middle Ages was the scene of a fair, held on 23 June, St Æthelthryth's feast day. It is particularly interesting that a site associated with Wærburh in the early material from Hanbury should also have links with Ely. ${ }^{47}$

Wærburh, then, was associated not only with Hanbury but with two other Mercian cult centres. There was also a pre-Conquest dedication to the saint in London, which may just possibly go back to the gth century, and which will be discussed shortly. All this suggests a major early cult with strong royal patronage. A particularly interesting aspect of this was the cult's diffusion in Kent from a relatively early period. An ancient dedication to the saint, on the opposite bank of the Medway to Sheppey, is first mentioned in the 12th-century Textus Roffensis, and was also known to the Chester monk, Henry Bradshaw, who makes Hoo the scene of one of Wærburh's miracles. ${ }^{48}$ Hoo St Werburgh seems to have been an early estate centre, the focus of a primitive regio perhaps originally embracing the whole of the Hoo peninsula. The church itself was a royal foundation, listed among eight diocesan "monasteries" in the 9th-century version of King Wihtred's privilege. It had a very extensive ancient

\footnotetext{
43 VWer., Ch. 7 (pp. 42-44).

$44 \quad$ VCH Northants 1, p. 346.

45 H.M. and J. Taylor, Anglo-Saxon Architecture, 3 vols (Cambridge, 1965-78), 2:594-96.

46 GDB, fols. $341 \mathrm{v}, 365 \mathrm{v}, 370$.

47 Roffe, "Seventh-Century Monastery," pp. 31-33; GDB, fol. 356.

48 P.H. Sawyer, ed., Textus Roffensis, Early English Manuscripts in Facsimile 11 (Copenhagen, 1962), fol. 221; Bradshaw, Life, I, lines 2788-2815 (p. 102); G. Ward, "Saxon Churches in the Textus Roffensis," Archaeologia Cantiana 44 (1932), 39-59.
} 
parish, originally presumably coterminous with the regio of the Howara, the people of Hoo, and almost certainly it should be viewed as a Kentish 'primary minster'. It was indeed the only such community known in the diocese of Rochester apart from the cathedral itself. ${ }^{49}$ The special position of the Hoo and its people is indicated by their responsibility for the repair of two piers of the bridge of Rochester; only the archbishop of Canterbury and the bishop of Rochester had commensurate obligations. ${ }^{50}$ Interestingly too the early minster parish of Hoo, like Weedon and Threekingham, was associated with a Stowe place name, in this case High Halstow, which Alan Everitt has described as "what was once the 'holy stow' of Hoo, on its commanding promontory overlooking St Werburga's minster, down by the Medway."51

The royal minster at Hoo appears to have been founded by King Cædwalla of Wessex at the time of his partial conquest of Kent in 686-87 in conjunction with members of the East Saxon royal house, one of whom was ruling in western Kent. ${ }^{52}$ Its early charters are conflated in a document which formed part of the archive of the great Mercian monastery of Medeshamstede (Peterborough), evidence that it had some close connection with that house from a very early date. It is presumably through this Mercian connection that the cult of Wærburh was introduced into Hoo. ${ }^{53}$ The saint would have been a highly appropriate patron for a Kentish-Mercian community. Interestingly, the Life of Eormenhild, wife of the Mercian King Wulfhere and Wærburh's Kentish mother, takes up this theme and says explicitly that the queen was a mediatrix between the men of Kent and the Mercians. ${ }^{54}$

Hoo then would have been an obvious centre for any attempt to foster links between Mercia and Kent during the period of the Mercian hegemony. The Mercian takeover of Kent in the late 8th and gth centuries seems to have been greatly resented, and the promotion of the cult of St Wærburh at Hoo would fit nicely into such a context; the half-Mercian, half-Kentish saint would have

49 Alan Everitt, Continuity and Colonization. The Evolution of Kentish Settlement (Leicester, 1986), 99, 187-88, 190, 192-93, 284-92; Nicholas Brooks, The Early History of the Church of Canterbury (Leicester, 1984), pp. 194, 205-06; Rollason, Mildrith Legend, pp. 46, 48.

$5^{0}$ A.J. Robertson, ed., Anglo-Saxon Charters (Cambridge, 1939), no. $5^{2}$ (pp. 106, 108).

$5^{1}$ Everitt, Continuity and Colonization, p. 292.

52 It seems that one of the founders was the invader Swæfred, son of King Sebbi of the East Saxons and joint king of Kent with Wihtred. Swæfred acknowledged the overlordship of the Mercian king Æthelred: S. Kelly, ed., Charters of St Augustine’s Abbey, Canterbury (London, 1995), pp. 196-97.

Rollason, Mildrith Legend, p. 46; F.M. Stenton, Preparatory to Anglo-Saxon England, ed. D.M. Stenton (Oxford, 1970), pp. 189-9o; S 68, 233.

54 "Tradita ... est a patre rege Erconberto Wlfero regi Merciorum, hacque mediatrice Cantuarii et Mercii facti sunt uti unum regnum": Love, Goscelin, p. 12. 
been a very suitable patron of efforts to sweeten the bitterness of political dependency. ${ }^{55}$ If such was indeed the case, it is especially interesting that when in 823 the Mercian King Ceolwulf granted land in Canterbury to Archbishop Wulfred he performed the deed at a royal vill called Werburging wic, "Wærburh's wic or trading centre. 56 This place-name occurs again, some 20 years later, as the location of his successor Beorhtwulf's confirmation in 844 or 845 of a grant by King Æthelbald (716-57) to the church of Rochester. ${ }^{57}$ Now of course we cannot be certain that the Wærburh who gave her name to this royal centre was the saint. But Wærburh is not an especially common name, ${ }^{58}$ and in the 8th and gth centuries seems to have been borne principally by women associated with the saint's own family, namely the wife of King Wihtred of Kent $(690-725)^{59}$ and the wife or daughter of the saint's cousin, King Ceolred of Mercia. ${ }^{60}$ (A third Wærburh was wife of a late gth-century ealdorman). ${ }^{61} \mathrm{Al}$ most nothing is known of any of these women, and it seems much more likely therefore that the eponymous figure of this Mercian royal vill was the saint. ${ }^{62}$

Both grants at Werburging wic have a very strong Mercian-Kent-London context. The nature of the grant of 823 involved Ceolwulf in his capacity as king of Kent, and the fact that Archbishop Wulfred himself wrote the charter

55 Barbara Yorke, Kings and Kingdoms of Early Anglo-Saxon England (London, 1990), pp. 31-33, 42 .

$56 \quad \mathrm{~S} 187$.

57 S 88.

58 Only four bearers of he name are known: PASE, s.v. "Wærburg."

59 Kelly, Charters of St Augustine's, p. 103. Kelly suggests that this queen was the patron saint of Hoo, but there is no evidence that she was ever culted and in any case the Mercian associations of Hoo render this very unlikely indeed.

6o ASC, s.a. 782. The Chronicle sources allege that this woman was Ceolred's queen. It has been suggested that she was Ceolred's daughter but there is no apparent basis for this: Handbook of British Chronology, ed. E.B. Fryde et al., 3rd ed. (London, 1986), p. 16.

61 PASE, s.v. "Alfred 18," where it is suggested he was ealdorman of Surrey, with the dates 863-870×899. Cf. Brooks, who suggests he was a Kentish ealdorman: Early History, p. 151.

62 It may be significant that the reign of Ceolwulf appears to mark a revival of interest in Wærburh. With the accession of Ceolred's exiled rival and distant relative Æthelbald (716-57), Æthelbald's kinsman and counsellor Guthlac seems to have taken on Wærburh's role as patron of the ruling house (see B. Colgrave, ed. and trans., Felix's Life of Guthlac (Cambridge, 1956), esp. Chs. 40, 42, 45, 49, 51-52; A.T. Thacker, "Guthlac and his Life: Felix Shapes the Saint," in Guthlac: Crowland's Saint, ed. J. Roberts and A.T. Thacker (Donington, in press), pp. 1-24, esp. 1-2, 22-23). Ceolwulf himself belonged to a dynasty established only with the accession of his brother Coenwulf in 798, the alliterating names of which recall those of Ceolred and his cousin and predecessor Coenred (Yorke, Kings and Kingdoms, pp. 104, 111, 118-19). The new dynasty perhaps wished to be linked with the earlier rulers, grandsons of Penda, and hence favoured Wærburh, the dynastic saint of that branch of the royal kindred. 
and was included among the attestors along with the East Anglian subregulus Sigered, suggest a meeting place in the South-East, if not in Kent itself. ${ }^{63}$ The grant of 844 or 845 involved important trading privileges in London belonging to Kent's second see. It thus seems possible that Werburging wic was not Hanbury, as we might expect, but some other settlement in the South-East, not too far from London, which in the earlier 9th century constituted an appropriate place for the Mercian king and Kentish bishops to transact business. As was long ago pointed out, Hoo is a very plausible identification of this otherwise unknown vill. ${ }^{64}$ It has a coastal location, appropriate to a wic, and is on the borders of Mercia, Essex and Kent.

Now this identification has been contested. Simon Keynes has argued that in the early gth century the Mercian conquerors of Kent kept their distance from the kingdom, even when dealing with the archbishop. ${ }^{65}$ But although this may have been the case under King Cenwulf (796-821), the situation was clearly changing under his successor Ceolwulf, when king and archbishop were on sufficiently good terms to meet. Thereafter of six recorded negotiations about property and rights between Kentish bishops and Mercian kings, two as we have seen involved Werburging wic. ${ }^{66}$ A more significant objection to the identification with Hoo is, perhaps, the fact that when Beorhtwulf issued his confirmation at Werburging wic in the 840s Kent was no longer in Mercian hands. Yet, as Keynes himself has noted, it seems likely that in this reign London, also lost to the West Saxons, returned to the Mercian sphere of influence. ${ }^{67}$ Perhaps the ancient royal vill of Hoo (highly accessible from London) returned with it. Hoo moreover was very near Rochester, the see of the beneficiary of Beorhtwulf's charter.

Two other of the six transactions just mentioned were made at the famous council site of Clofesho. ${ }^{68}$ Was that too within the Hoo estate? It has long been argued by Stubbs and more recently by Ward, Wallace-Hadrill and VollrathReichelt that it is to be identified with Cliffe-at-Hoo, which lies on the north side of the Hoo peninsula. ${ }^{69}$ Keynes has dismissed this identification since the first element of Cliffe is OE clif, not clof and the place-name Clofesho denotes

\footnotetext{
63 Brooks, Early History, pp. 168, 360.

64 E.g. G. Ward, "The Forgotten Saxon Nunnery of St Werburg at Hoo," Arch. Cant. 47 (1935), 117-25, esp. 122-23.

65 Simon Keynes, "The Control of Kent in the Ninth Century," EME 2 (1993), 111-31.

66 S 88, 187, the others being S 186, 188, 1434, 1436.

67 Keynes, “Control of Kent," p. 127.

68 S 1434 (824); S 1436 (825).

69 Ward, "Forgotten Saxon Nunnery," pp. 122-23; J.M. Wallace-Hadrill, Bede's Ecclesiastical History of the English People: A Historical Commentary (Oxford, 1988), p. 143.
} 
"the hill spur (or spurs) of a particular valley or cleft."70 Nevertheless, Cliffe-atHoo was, like Hoo St Werburg itself, an important early estate centre at the terminus of a Roman road. Its church, originally perhaps subordinate to Hoo St Werburg, though later an important centre in its own right, bears the suggestive dedication of St Helen. ${ }^{71}$ It remains a least possible that the revival of Clofesho during the period of the Mercian hegemony as a site for ecclesiastical councils, a use first prescribed by Theodore in 672 , was linked with its being sited on an estate such as Hoo linked with a saint who was both Mercian and Kantish. Clearly a plausible case can be made for Clofesho being regarded as a place where king and Kentish bishops could meet on equal terms. ${ }^{72}$

I would argue then that Wærburh was a royal saint whose cult was fostered by the Mercian kings and their dependants at a number of important and widely dispersed centres in the 8th and 9th centuries. Enshrined at the monastery of Hanbury, she was venerated at a number of other royal monasteries and minsters, both in the Mercian heartland and beyond. The cult did more than enhance the prestige of her particular branch of the royal kindred; it had political overtones, and by virtue of these seems to have remained significant as late as the $9^{\text {th }}$ century when the Mercian kingship belonged to men distantly if at all related to the line of Wulfhere, Wærburh's own branch of the royal kindred. By reconstructing the foci of this major cult we may disinter something of the geography of political power within pre-Viking Mercia.

\section{The Pre-conquest Cult at Chester and its Diffusion}

Wærburh's remains were certainly enshrined at Chester by 958, when King Edgar made a grant of lands to the saint's familia there. ${ }^{73}$ The date of their arrival is, however, difficult to ascertain. A late tradition, recounted by the Chester monk Ranulf Higden, relates that because of the Danish raids on Mercia (which culminated in 874 in the flight of the king and the encampment of the invaders around the nearby royal monastery of Repton), the Hanbury

\footnotetext{
$70 \quad$ S.D. Keynes, The Councils of Clofesho, Vaughan Paper 38 (Leicester, 1993), pp. 14-15.

71 Everitt, Continuity and Colonization, pp. 194, 242-43.

72 For a summary of the councils meeting at Clofeshoh see Keynes, Councils of Clofesho, pp. 5-14, though he comes to a very different conclusion.

$73 \mathrm{~S} 667$. For the cult at Chester see $\mathrm{VCH} C \mathrm{Ch}$ ), 1-25, at pp. 18-19; idem, "Chester and Gloucester: Early Ecclesiastical Organization in Two Mercian Burhs," Northern History 18 (1982), 199-211, at pp. 203-04, 209.
} 
community fled from their home. ${ }^{74}$ Taking the shrine containing the holy relics, by then crumbled into dust, they came to Chester. Higden says nothing of the arrangements made for their reception, but claims that from the time of King Æthelstan there existed a minster of canons to serve the saint. In itself, the story of the flight from Hanbury is not improbable-the journeyings of St Cuthbert and his community provide an obvious parallel—but the episode has long been doubted, partly because the Anglo-Saxon Chronicle described Chester itself as a deserted place in the annal for $893 .{ }^{75}$

As I have argued elsewhere, a more plausible context for the coming of Wærburh's relics to Chester is provided by material first recorded by the 16thcentury monk, Henry Bradshaw. Bradshaw depicts the rulers of Mercia, Alfred's daughter Æthelflæd and her husband Æthelred, as primary patrons of the cult and adds that they set up the shrine in the church of SS Peter and Paul, the mother church of Chester, which they enlarged and dedicated to the saint. ${ }^{76}$ This later date would make more sense of the tradition that her body crumbled to dust to avoid impious pollution-there would have been no threat of this if the body had been removed in advance of the Danes (St Cuthbert's body, after all, survived). It would also make sense of the attachment of Hanbury to Chester-not an arrangement likely to have been effected in the 870 . $^{77}$

The sources for Bradshaw's account are lost. He depended chiefly on a volume which he termed the "third passionary" and which apparently contained the Lives of St Wærburh and the Ely abbesses, free of the Sheppey material imported in the mid-12th century and displaying no knowledge of the traditions which made Wærburh and her mother abbesses of Ely. Besides material evidently imported from Ely in the early 12th century, the third passionary also contained matter of local, Cestrian, origin, in particular, accounts of the saint's translation and the miracles she performed thereafter. ${ }^{78}$ Since the sequence of the miracles ends in 1180, there are reasons for thinking that the volume was compiled shortly after that date, a period which also saw the production of Lucian's De Laude Cestriae, a Chester service book, and a calendar. ${ }^{79}$ It is not at all

74 Higden, Polychronicon 6:126-28, 366; Bradshaw, Life, pp. 149-52.

$75 \quad A s c$, s.a. 893 (Mss C, D, s.a. 894; omitted in MS E).

76 Bradshaw, Life, I, lines 527-666 (pp. 149-53).

77 For a different view, reaffirming the traditional date, see C.P. Lewis, "Edgar, Chester and the Kingdom of the Mercians," in Edgar, King of the English, 959-75: New Interpretations, ed. Donald Scragg (Woodbridge, 2007), pp. 104-23, at p. 115.

78 Bradshaw, Life I, lines 694-96, 3246; II, lines 169o-5 (pp. 32, 117, 188).

79 M.V. Taylor, ed., Liber Luciani de Laude Cestrie, Record Society of Lancashire and Cheshire [RSLC] 64 (1912); Bodleian Library, MS Tanner 169*; Wormald, Eng. Ben Kal. after 110o, I, 95-96. 
unlikely that some record of the translation was kept at Chester from a relatively early period.

Chester was an important centre for Æthelflæd, and in 907 she caused it to be refortified, evidently as part of the defence of Wirral against Norse invasions from Ireland. ${ }^{80}$ Moreover, she and her husband had already shown interest in the cult of Wærburh's relative St Mildburh, in whose honour they gave a valuable golden chalice to the church of Wenlock. ${ }^{81}$ Even more significantly, in 909, two years after the refortification of Chester, Æthelflæd was responsible for the translation of St Oswald, the 7th-century Northumbrian king enshrined in the royal Mercian monastery of Bardney (Lincs.), to a new foundation in her fortified capital of Gloucester. ${ }^{82}$ The cult of St Oswald was associated with that of Wærburh in Chester by $c .1200$ at the latest, and it may be that, as Bradshaw alleges in his poem, it was introduced into the city by Æthelflæd..$^{83}$ Æthelflæd's conquest of Staffordshire in 913 offered her ample opportunity to introduce the relics from Hanbury. Some reorganization of local cult centres consequent upon that conquest provides a much more plausible context for the acquisition of Hanbury by the minster at Chester than the romantic story of the flight of the clergy before the marauding Danes. ${ }^{84}$ It also suggests that like Oswald, Wærburh's was a cult that had considerable resonance for the royal families of pre-Viking England.

With the removal of the relics to Chester the cult takes a new course. St Wærburh becomes the patron of a royal burh and as such a mediator between the much reduced Mercians of the early 1oth century and their alien West Saxon rulers, rather as she had been between the Mercians and the men of Kent in the gth century. Little, however, is known of her cult thereafter in late AngloSaxon Chester. It may have been promoted by Kings Æthelstan and Edmund, both of whom are said by late traditions to have founded a house of canons in her honour. ${ }^{85}$ That the saint continued to be venerated there is clear from King Edgar's grant of $958,{ }^{86}$ and the enrichment of her church with precious ornaments by Earl Leofric of Mercia (d. 1057). ${ }^{87}$ But it is not until the time

\footnotetext{
8o VCH Cheshire 1, pp. 249-50; 5:1, pp. 17-19.

81 S 221.

82 ASC, MSS A, B, s.a. 909 (C, D, s.a. 910); Thacker, “Chester and Gloucester," pp. 203-04.

83 Bradshaw, Life, I, lines $636-38$ (p. 152); Thacker, "Kings, Saints and Monasteries," pp. 18-19.

84 Chart. Chester Abbey I, pp. x, xiv; F.T. Wainwright, Scandinavian England (Chichester, 1975), pp. 310-14; Marios Costambeys, "Æthelflæd [Ethelfleda]" in $O D N B<$ https://doi .org/10.1093/ref:odnb/8907>.

85 Higden, Polychronicon V1, pp. 128-29; Bradshaw, Life I, lines 597-6o3 (p. 151); vcH Ches. 3, p. 132.

86 Chart. Chester Abbey I, pp. xvii-xviii, 10-13; S 667; S 667.

87 JW vol. 2, p. $5^{82}$.
} 
William of Malmesbury in the 12th century that there is any contemporary witness that wonders were wrought at the shrine. Otherwise there is only the very late evidence of Bradshaw about favours wrought for the canons of the preConquest minster, evidence to which we shall return in a moment.

Outside Chester, the saint enjoyed a modest reputation in late Anglo-Saxon times. The feast day of her deposition (3 February) was known in Canterbury by c. 1000, and in all occurs in some seven calendars dating from before $1100 .{ }^{88}$ She was also invoked in two or three early litanies during the same period. ${ }^{89}$ Besides those already mentioned in Hanbury, Chester, and Hoo, there are a few other plausibly pre-Conquest dedications, including most significantly those at London and Derby. ${ }^{90}$ The London evidence is especially interesting; the church, which lay south of Cheapside at the junction of Watling Street and Friday Street, is first recorded c. 1100 in the possession of Christ Church, Canterbury. Previously held by one Gumbert, it had a house next door and almost certainly dates back at least to late Anglo-Saxon times. ${ }^{91}$ Like the church of St Bride, Fleet Street, it may well derive from some Chester merchants then active in London. It is tempting, however, to speculate that it may be the product of earlier 9th-century royal sponsorship. Wærburh is precisely the sort of saint we might expect to be promoted in London by the Mercian kings. The church of St Alban, Wood Street, which lay to the north of St Werburgh's, would provide an analogy, if as was formerly believed, its earliest building dates back to the 8th or 9th century. ${ }^{92}$ More recently, however, it has been suggested that that too is a late Anglo-Saxon foundation. ${ }^{93}$ The problem must remain unresolved; but at the very least there remains the possibility that the cult of Wærburh was introduced into London by the Mercian kings.

In or near Derby, there are two probable pre-Conquest dedications to St Werburgh: one in Cheapside at the heart of the late Anglo-Saxon town, the other at Spondon just outside. In both cases it seems very probable that the churches

88 Wormald, Eng. Kal. before 110o, pp. 31, 59, 73, 199, 213, 255. Her deposition was also added to a Sherborne calendar in the 11th century: Wormald, p. 185. Rushforth, Saints in Eng. Kal., no. 19 .

89 M. Lapidge, ed., Anglo-Saxon Litanies of the Saints, HBS 106 (1991, for 1989-90), pp. 118, 145, 238 (nos. vi.129; xii.162; xxxii. 129).

90 Cf. also churches at Blackwell (Derbs.):J.C. Cox, Notes on the Churches of Derbyshire, 4 vols (Chesterfield, 1875-79) 1:93-94; Kingsley (Staffs.).

91 D.C. Douglas and G.W. Greenaway, eds. and trans., English Historical Documents vol. 2, 1042-1189, 2nd ed. (London, 1981), no. 280; B.W. Kissan, "An Early List of London Properties," Transactions of the London and Middlesex Archaeological Society n.s., 8 (1940), 57-69, at pp. $58,60,65$.

92 W.F. Grimes, Excavation of Roman and Medieval London (London, 1968), pp. 203-09.

93 G. Milne, Excavations in Medieval Cripplegate, London (Swindon, 2001), pp. 86-100. 
themselves pre-date the Conquest, but the dedications only emerge in the 12th century. The church in Cheapside, which had a parish by 1140 and a cemetery by 1200, was almost certainly among the six Derby churches listed in Domesday. Its dedication, however, was only disclosed when it was confirmed to the canons of Darley abbey by Walter Durdent, bishop of Lichfield in the 1150 . ${ }^{94}$ At Spondon there was a church and a priest by 1086, and the dedication becomes apparent when the church was given by William de Ferrers to the hospital of Burton Lazarus in the reign of Henry II. ${ }^{95}$ Two such potentially early occurrences of a relatively rare dedication suggest that the cult of St Wærburh had especial significance in pre-Conquest Derby. One possibility is that the cult was introduced by Æthelflæd herself, after the conquest of the town in $917 .{ }^{96}$ She may indeed have had a longstanding interest in the area; her husband Æthelred together with her brother Edward the Elder were already purchasing land at Hope and Asford in Derbyshire before Æthelred's death in 911. That transaction is thus likely to have been very much at the time that he and Æthelflæd were responsible for the translation of Oswald of Northumbria in $909 .{ }^{97}$

There is, however, another possible explanation of the Cheapside dedication. The church, which belonged to Leofric in 1066, was probably held in 1086 by Ralph fitz Hubert, lord of Crich, and one of the most important barons in Derbyshire. ${ }^{98}$ Leofric is presumably to be identified with the man of that name who in association with Leofnoth was one Ralph's principal antecessors elsewhere in Derbyshire. These substantial pre-Conquest landholders were probably brothers, successors in many of his estates of the royal minister Morcar. Morcar and his brother Sigeferth were designated chief thegns of the Seven Boroughs (which included Derby) when they were treacherously murdered by the Mercian ealdorman Eadric Streona in $1015 .{ }^{99}$ Now Morcar was probably married to the niece, and was certainly one of the principal lay heirs, of Wulfric Spot (d. 1002×4), the rich and royally descended thegn who held land on Wirral, probably the great estate of Eastham just outside Chester. ${ }^{100}$ The link with Wærburh may therefore go back to Wulfric and his family.

94 GDB, fol. 28ov.; vCH Derbs. 1, p. 327; R.R. Darlington, ed., Cartulary of Darley Abbey, 2 vols (Kendal, 1945), 1: liii-liv, 108, 204; 2:595-96.

95 Cox, Churches of Derbyshire, 3:293, 296; vCH Derbs. 1, p. 343.

96 R.A. Hall, "The Pre-Conquest Burgh of Derby," Derbyshire Archaeological Journal 94 (1976, for 1974), 16-23.

97 S 397; P.H. Sawyer, ed., Charters of Burton Abbey (London, 1979), pp. 5-7.

$98 \quad$ VCH Derbys. 1, p. 305; Cart. Darley Abbey 1, pp. liii-liv.

99 Asc C(DE) 1015; Charters of Burton Abbey, pp. xli-xliii.

$100 \quad V C H$ Derbys. 1, pp. 305-06; VCH Cheshire 1, p. 264; Charters of Burton Abbey, pp. xviii, xxiv, 54 . 


\section{The Cult in Chester after the Norman Conquest}

It is clear that the advent of the Normans gave fresh impetus to Wærburh's cult. Earl Hugh I's refoundation of the minster as a great Benedictine abbey in the late 1080 s and early 109os undoubtedly enhanced Wærburh's status. ${ }^{101}$ It was an enterprise in which the Norman abbey of Bec was much involved. Hugh's closest friend among the higher clergy, the prelate chosen to dedicate his new foundation, was Anselm, abbot of Bec, soon to become archbishop of Canterbury. ${ }^{102}$ The first abbot of Chester, Richard (1092-1116), was a monk of Bec and according to Ranulf Higden had been Anselm's chaplain. ${ }^{103}$ Interestingly, Richard of Clare, the abbot of Ely and patron of the royal cults there, installed by Henry I shortly after his accession in 1100, was also a monk of Bec and a protégé of Anselm. ${ }^{104}$ Those connections may go some way to explain the almost simultaneous development of Wærburh's cult in Chester and Ely at this time.

Earl Hugh, however, unlike Abbot Richard, does not seem to have engaged in elaborate translation ceremonies to promote his saint. His principal contribution, apart from the establishment of the monastery itself, was the grant to his new foundation of a midsummer fair focused upon a secondary feast, that of St Wærburh in the summer (in aestate) celebrated on 21 June. ${ }^{105}$ We do not know the origins of this feast, which by the 13th century was also referred to as the feast of the Translation of St Wærburh. ${ }^{106}$ In Bradshaw's time it was believed to commemorate the day of Wærburh's initial elevation by King Ceolred, when her body was found to be incorrupt. ${ }^{107}$ It may therefore have been long established locally. At all events, although it is not to be found in any preConquest calendar, by the 12th century it had become the saint's principal day in the North-West. The fair and the feast on which it was centred was clearly a matter of considerable importance to the Anglo-Norman earls, and the organization of these events was the subject of a number of charters. ${ }^{108}$ The feast was given great prominence in a still surviving late 12th-century service book

\footnotetext{
$101 \quad$ VCH Ches. 3, p. 132-34; 5:1, pp. 30-31.

102 On Hugh I's connexions with Bec see G. Barraclough, ed., The Charters of the AngloNorman Earls of Chester, RSLC 126 (1988), no. 4; Chart. Chester Abbey I, pp. xxiii-xxv.

103 M.V. Taylor, ed., Obits of Abbots of Chester, RSLC 64 (1912), p. 94; VCH Ches. 2, p, 133; Higden, Polychroncon VII, p. 360.

104 LE II.140, 144-48 (ed. Blake, pp. 224, 228-34); VCH Cambs. 2, 203.

105 Chart. Chester Abbey I, p. 21.

106 R. Stewart-Brown, ed., Calendar of Chester County Court Rolls, Chetham Society, new ser., 84 (Manchester, 1925), pp. 122-23.

107 Bradshaw, Life I, lines 3449-3455 (p. 124), citing Ranulf of Higden's Polychronicon, although in fact Higden says nothing about the day on which the translation took place.

108 Chart. Chester Abbey I, pp. 21, 46-48, 52-53, 68-69; VCH Ches. 5:2, p. 100.
} 
(to which I shall return). ${ }^{109}$ The growing importance of the summer feast (and very probably the cult as a whole) in this period is reflected by its addition to a number of calendars, including those from Abingdon, Worcester, and Sherborne, in the 12th century. ${ }^{110}$ It is also reflected in the development of a tradition which located Wærburh herself at Chester and made the city the scene of an embellished version of her most famous miracle, that of the obedience of the wild geese. That Chester gloss on the traditions of Hanbury and Ely was recorded by both William of Malmesbury and Henry of Huntingdon before the mid-12th century. ${ }^{11}$

The post-Conquest period probably also saw the establishment of some new church dedications. By c.1200, for example, Wærburh was dedicatee of the church of a newly-established Premonstatensian community in Warburton (Cheshire), a vill which had briefly belonged to Chester abbey in the early 12th century. ${ }^{112}$ By the later 12th century, there were churches dedicated to Wærburh in the cities of Bristoll13 and Dublin, ${ }^{114}$ with both of which Chester had significant trading links. There was also a chapel with its own cemetery in Shrewsbury, near the episcopal church of St Chad. ${ }^{115}$

There was an important efflorescence of writing about Wærburh at Chester abbey in the late 12th century. The best evidence of this is the still extant service book, which contained amongst other things an office for her feast and a litany in which she is given exceptional precedence over other female saints

109 The grading, "in copes with twelve lections," was added in the 13th century. The feast of the deposition was even more highly rated, in red with an octave. See Bodl., Tanner MS $169^{*}$, pp. 4, 8; Wormald, Eng. Ben. Kal. after 110o, I, pp. 95-96, 101, 105.

110 Cambridge, Corpus Christi College, MS 57, fol. 65; Wormald, Eng. Kal. before 110o, pp. 189, 217: Rushforth, Saints in Eng. Kal., nos. 19, 21. Cf. also the addition of the 3 Feb. feast in red to a Worcester calendar in the 12th century: Wormald, Eng. Kal. before 1100, p. 213; Rushforth, Saints in Eng. Kal., no. 21.

111 WM, GPA 1:172.5-9 (pp. 466-68); HH, pp. 692-94.

112 G. Ormerod, History of the County Palatine and City of Chester, 2nd ed., revised by T. Helsby, 3 vols (London, 1882), 1:567; Chart. Chester Abbey, 1:52, 59, 60, 61.

113 Bristol: the church of St Werburgh in the important intramural thoroughfare of Corn Street was in existence by the late 116os when it was granted to Keynsham Abbey by Earl William of Gloucester: W. Dugdale, Monasticon Anglicanum, 6 vols in 8 (London, 1817-30), 6(1), p. 453. Cf. R.B. Patterson, ed., Earldom of Chester Charters (Oxford, 1973), pp. 41-42, 49 (no. 17); William of Worcestre, The Topography of Medieval Bristol (Bristol Record Society, 2000), p. 202 (no. 359).

114 The parish church of Dublin castle was established at the latest by the 1170s, but possibly considerably earlier: H.B. Clarke, "Christian Cults and Cult Centres in Hiberno-Norse Dublin," in The Island of St Patrick, ed. A. MacShamhráin (Dublin, 2004), pp. 140-58, at 144-45.

$115 V C H$ Salop. via, p. 23. 
and martyrs. ${ }^{116}$ In addition, there is the work of the monk Lucian, De Laude Cestriae ("In praise of Chester"). Lucian emphasizes the number and variety of the city's saintly protectors, among whom the holy Virgin Wærburh was preeminent. The ever watchful guardian of the Northgate, her activities reinforced by her company of monks at prayer both day and night, she had recently given proof of her efficacy by saving the city from fire. ${ }^{117}$ Most tantalizing of all is the lost "third passionary,"118 which formed Bradshaw's principal source and included a version of the Vita Werburgae, imported from Ely in its early 12thcentury form, and a record of the saint's miracles in Chester from the 1oth to the late 12 th centuries. ${ }^{119}$

The miracles related in the third passionary evidently extended from an incident ascribed to the reign of Edward the Elder (899-924) to 1180, when the saint's relics were borne in procession to quell a great fire in the city. The record is divided into sections concerning the canons of the Anglo-Saxon minster and the monks of the new Benedictine foundation. The first to be recorded by Bradshaw tells how the canons took St Wærburh's shrine to the walls of the city when it was besieged by a Welsh king called "Griffin." The shrine was damaged by a stone thrown by one of the attackers, and as a result the Welsh king and his host were smitten with blindness and retreated. ${ }^{120}$ The episode is placed by Bradshaw in the reign of King Edward the Elder, and if authentic would of course be excellent evidence for the presence of Wærburh's relics in early 1oth-century Chester. It seems more likely, however, that Bradshaw confused his Edwards and that the incident should properly be ascribed to the reign of Edward the Confessor. We know little of Edward the Elder's relations with the Welsh, and when he is in conflict with them the men of Chester were their allies. ${ }^{121}$ On the other hand, a Griffin does appear in contemporary sources for the Confessor's reign and is to be identified with Gruffudd ap Llywelyn, the 11th-century king of Gwynedd who was active against the English in the mid -1050s. ${ }^{122}$

116 E. Danbury, "The Intellectual Life of the Abbey of St Werburgh, Chester, in the Middle Ages," in Medieval Archaeology, Art and Architecture at Chester, ed. A.T. Thacker, British Archaeological Association Conference Trans. 22 (Leeds, 2000), pp. 107-20, at pp. 108-10; Wormald, Eng. Ben. Kal. after 1100, I, pp. 95-96.

117 Lucian, De Laude Cestriae, pp. 54-6o; R.C. Christie, ed., Annales Cestrienses, RSLC 14 (1886), p. 28.

118 Bradshaw, Life I, lines 694-96, 3246; II, lines 1690-5 (pp. 32, 117, 188). Cf. discussion by Horstmann, Life of Werburge, pp xvi-xix, and Love, Goscelin, pp. lviii, cxviii-cxix.

119 Bradshaw, Life II, lines 667-1681 (pp. 153-88).

120 Bradshaw, Life II, lines 681-729 (pp. 154-55).

121 WM, GRA, 1:350 (Ch. 196.3), 420 (Ch. 228.8); 2:186-87.

$122 V Æ d R$, 2nd ed., pp. 64 (where Gruffudd is linked with an unnamed king of the Scots), 86-88; ASC, MSs CD, s.a. 1055, 1056, 1058; J. Tait, ed. Domesday Survey of Cheshire, Chetham 
Another of Bradshaw's miracles is very similar and is perhaps based upon an even more garbled version of the same incident. During an attack on Chester by Harold of Denmark, Malcolm of Scotland, and the "king of Goths and Galwedy," the canons again parade with the shrine, it is again damaged, and the man responsible is possessed by devils and dies, a sign which causes the attackers to abandon the city. ${ }^{123}$ It is impossible to make much of this, though it may represent a confused memory of an incident of the 1050s, when, for example, Gruffudd intrigued with others including Earl Ælfgar of Mercia, Magnus, son of Harold Hardrada of Norway, and the men of the Isles. ${ }^{124}$

A few other stories in the pre-Conquest section of the record contain some circumstantial information. One refers to the cure of a canon called Ulminus who broke his leg while hunting. ${ }^{125}$ Another describes attempts by the inhabitants of Wirral to devastate the saint's park at Upton and the punishment meted out to them. Though Upton is listed among the possessions granted by Edgar in 958, the name is in a late form, and in any case the community no longer held an estate there in 1066. Upton was certainly granted to St Werburgh's abbey by Earl Ranulph I (1121-28/9), and the story is therefore more likely to be of post-Conquest origin. ${ }^{126}$ Such evidence, combined with the garbling of the Anglo-Saxon tradition, suggests that the whole liber miraculorum in the third passionary was compiled after the Conquest, probably in the 12th century. It also ties in with the much more circumstantial detail in the postConquest material, which besides the story of the fire of 1180 includes lengthy anecdotes from the time of Earl Richard (1101-20).127

Some of these later stories present Wærburh in a special relationship with the Norman earls and their retainers. Invoked, for example, by the constable William fitzNigel, she divides the waters of Dee to enable him to cross to Basingwerk to bring succour to Earl Richard then threatened by the wild and wicked Welsh. ${ }^{128}$ In another, she is presented as protectress of the monastery against the comital family. Richard, originally a benefactor of the abbey and as we have seen favoured by Wærburh, was turned against the community by his wife, who prevailed upon him to demand that the abbot surrender to him the

Society, new series, 75 (Manchester, 1916), pp. 22-23, 90-91, 242-43; R.R. Davies, The Age of Conquest (Oxford, 1987), pp. 24-27; F.M. Stenton, Anglo-Saxon England, 3rd ed. (Oxford, 1971), pp. $572-76$.

123 Bradshaw, Life II, lines 758-99 (pp. 157-58).

124 Stenton, Anglo-Saxon England, pp. 574-75.

125 Bradshaw, Life II, lines 1038-1107 (pp. 166-69).

126 Bradshaw, Life II, lines 989-1037 (pp. 165-66); Chart. Chester Abbey I, pp. xxviii, 46-52. The reference to hunting parks has a post-Conquest feel.

127 Bradshaw, Life II, lines 1416-1597 (pp. 179-85).

128 Bradshaw, Life II, lines 1416-85 (pp. 179-81). 
great manor of Saighton by Chester. When he and his wife were drowned in the famous wreck of the White Ship the saint appeared to the sacristan to announce the death of his community's adversary.129

Most importantly, perhaps, the post-Conquest stories present Wærburh as protectress of Chester itself. Bradshaw has a particularly circumstantial account of the saint's defence of the city in the great fire of 1180 . The fire having quickly consumed a great part of the town including the minster of St Michael at the Roman south gate, the monks came forth from the abbey bearing the shrine of St Wærburh and chanting litanies. They moved around the fire and (helped as Bradshaw acknowledges by the citizens) the blaze was extinguished. The citizens expressed their gratitude in a solemn procession of thanksgiving. This last story was undoubtedly current almost immediately after the event which it described since it was also recorded by Lucian, writing in the 119os. ${ }^{130}$

It is clear, then, that the advent of the Normans gave a fresh impetus to Wærburh's cult. Hugh's refoundation of the minster elevated the status of its patron. In particular, the establishment of a three-day fair around the summer feast ("St Werburg in Chester") gave great prominence to that day and by the 12th century it rivalled the traditional feast of 3 February. The late 12th and early 13th century seem to have marked the apogee of Wærburh's cult in Chester. It was the period when Ranulf III's promotion of the special, princely, status of the Cheshire core of his earldom was stimulating a growing sense of local identity, vis a vis both the English and Welsh. It was also the moment when the citizens of Chester were developing their own instruments of self government. ${ }^{131}$ Wærburh provided a figure around which these reformulated regional and civic identities could acrete. Her role in the fire of 1180 perhaps engendered a new level of popularity among the citizens, and the extension of the cult to trading centres such as Bristol and Dublin seems also likely to have been their work.

As elsewhere there is little to indicate that the Normans in Cheshire were hostile to established native saints. On the other hand the cult does seem to have become a distinctly local affair. Compared with the modest popularity that she enjoyed in the late Anglo-Saxon calendars, the saint received few notices after the Conquest. As might be expected, her death-day was commemorated at Ely and in one or two other communities, most notably perhaps in

129 Bradshaw, Life II, lines 1486-1597 (pp. 182-85).

130 Bradshaw, Life II, lines 1598-1681 (Ch. 20); Lucian, De laude Cestriae, pp. 30-31, 55 .

131 A.T. Thacker, "Introduction: the Earls and their Earldom," in The Earldom of Chester and its Charters, ed. A.T. Thacker, Journal of the Chester Archaeological Society 71 (1991), pp. $15^{-18 .}$ 
Shrewsbury's episcopal minster of St Chad, the 12th-century martyrology of which also included the translation feast (assigned to 20 June) and the feast day of Waerburh's mother, Eormenhild. ${ }^{132}$ Elsewhere the translation feast was neglected, even at Abingdon where it had been known before the Conquest. ${ }^{133}$ One possible indication of interest at this time may be the fictional passio of Wærburh's alleged brothers, Wulfhad and Ruffinus, which elaborates tradition about the saint with a story of an aborted marriage, associating her very closely with her Mercian royal relatives. ${ }^{134}$ Her supposed brothers were enshrined at Stone (Staffs.), an Augustinian priory founded in the reign of Henry I and probably succeeding a church dedicated to Wulfhad. ${ }^{135}$ The date of their passio, which does not mention Wærburh's enshrinement in Chester, remains however very uncertain. ${ }^{136}$

By the later 13th century, even in Chester, the cult's popularity had waned. The great earldom of which Wærburh had in some sense been the patron had been absorbed by the Crown. Among the citizenry, her cult had been eclipsed by that of the Holy Cross, promoted at Chester abbey's rival as an ecclesiastical centre, St John's. On the whole there were few bequests by the citizens to the abbey, and few chantries were established there after Henry III's foundation for Earl Ranulf III. ${ }^{137}$

\section{Conclusions}

In this chapter, I have sought to chart the changing fortunes of a cult which was fostered at a variety of times in a number of important centres in the NorthWest, the Midlands and the South-East and which in its various reinventions has been an important vehicle for fostering dynastic, regional and civic identity. Wærburh begins her posthumous career as patron of a specific royal lineage, that of the kings Wulfhere, Æthelred, Coenred and Ceolred. That lineage ended with the death of Ceolred in 716 . Thereafter her role changes. She is more

\footnotetext{
132 VCH Salop. IVa, pp. 22-23.

133 Eng. Ben. Kal. after the Conquest 2:118 (Crowland), 150 (Dunster); 2:9 (Ely).

134 Grosjean, "Cod. Goth. Appendix," pp. 183-87; Dugdale, Monasticon, 6:1, pp. 226-30.

$135 V C H$ Staffs. 3, p. 240.

136 In Dugdale's day a version of the passio formed the bulk of the Historia Fundationis, the opening section of a now lost or missing Cottonian manuscript, Otho A xvi: Monasticon 6:1, p. 226. That text was appended to the Peterborough Chronicle of Hugh Candidus in the 14th century: W.T. Mellows, ed., The Chronicle of Hugh Candidus (Oxford, 1949), pp. 140-59; BL, Add MS 39758.

137 vcH Ches.5:1, pp. 34, 85-86.
} 
important to later Mercian kings as patron of their dealings with Kent. Her strong associations with Mercia's former greatness explain why Æthelflæd sponsored her cult in Chester and perhaps elsewhere. The move to Chester set the cult on a new course. Plucked from her dynastic monastery and set up in an urban minster, Wærburh became patron first of a military garrison established by an alien royal family governing all that remained of Mercia after the Danish conquests and then of the rapidly developing city of her adoption. The final reinvention came after the Conquest, with Wærburh's new eminence as patron of a great Benedictine abbey and of the princely family that founded it. Once again a dynastic patron, she became also in a fuller sense a patron of the citizens themselves - with their emerging sense of civic identity and their strong sense of differentiation from their English and Welsh neighbours. It at this point probably that the cult is taken to fellow trading cities such as Bristol and Dublin. It is at this point too that the cult achieves its own literature. Paradoxically, perhaps, it was the Anglo-Normans in the 12th century who crystallised the image of this early Anglo-Saxon saint in the form that was to endure throughout the middle ages and receive its final rendering in Henry Bradshaw's vernacular Life. 